\title{
Adela Kożyczkowska, Anna Młynarczuk-Sokołowska, Kulturowe konteksty dzieciństwa. Szkice antropologiczno- -pedagogiczne, Wydawnictwo Naukowe Katedra, Gdańsk 2018, ss. 326
}

Intensyfikacja mobilności współczesnego człowieka oraz dynamiczne przemiany społeczno-kulturowe, które aktualnie obserwujemy na świecie, sprawiają, że kształt współczesnych społeczeństw ulega dynamicznym przeobrażeniom. Dotyczy to również Polski, która staje się coraz bardziej różnorodna narodowo, etnicznie, językowo. W dzisiejszych czasach różnorodność staje się naturalnym elementem rzeczywistości każdego człowieka, dlatego szczególnie istotne staje się poszukiwanie odpowiedzi na pytania dotyczące uwarunkowań ludzkiej egzystencji oraz edukacji w warunkach różnicy.

Recenzowana monografia poświęcona jest dziecku i dzieciństwu w różnych sytuacjach społeczno-kulturowych, dla których wspólnym punktem odniesienia jest różnica kulturowa i społeczna. Jak zauważają autorki książki, różnica ta może być konsekwencją przymusowej lub dobrowolnej migracji dorosłych. Tak się dzieje w przypadku uchodźstwa czy migracji zarobkowej, które są powodem szeregu problemów związanych z adaptacją dzieci i dorosłych do nowej sytuacji społeczno-kulturowej. Funkcjonowanie w roli migranta zmienia bowiem sytuację życiową człowieka - staje się on cudzoziemcem, członkiem mniejszościowej grupy, która cechuje się odmienną od większości przynależnością narodową oraz posługuje się obcym językiem. Migracje mają to do siebie, że bez względu na motyw wyjazdu zawsze wykorzeniają jednostkę z jakiegoś świata, kultury i języka, a tym samym

\footnotetext{
1 Katarzyna Szostak-Król, Szkoła Podstawowa nr 26 im. S. Staszica w Białymstoku, Polska, e-mail: kaszost@tlen.pl.
} 
zmuszają do funkcjonowania w nieznanym jej świecie, odnalezienia się w kulturze i języku kraju przyjmującego.

Recenzowana publikacja składa się z dwóch części: pierwsza to „Dziecko społeczeństwo: (wielo)kulturowe wytwarzanie dzieciństwa”, druga - „Dziecko - edukacja: (wielo)kulturowe przetwarzanie dzieciństwa”.

W pierwszej części książki „Dziecko - społeczeństwo: (wielo)kulturowe wytwarzanie dzieciństwa”, autorki podejmują próbę zgłębienia doświadczeń dziecka wytwarzanych na styku/spotkaniu/zderzeniu społeczeństw i kultur, które kształtują je jako byt społeczno-kulturowy. Omawiają dzieciństwo jako praktykę społeczną i jednocześnie jako część/element kultury w ogóle.

Część pierwszą otwiera rozdział „Dziecko - społeczeństwo - (wielo)kulturowość. Między tożsamością zranioną a/i tożsamością poszerzoną”. Została w nim podjęta próba rozpoznania dziecka i dzieciństwa w odniesieniu do kulturowego ujęcia relacji Swoi - Nie-swoi. Autorki interesuje także dziecko i dzieciństwo jako wytwory świadomości społecznej. Takie ujęcie pozwala widzieć obie kategorie jako konstrukty społeczno-kulturowe i kontekstowo osłodzić je w swoistym kontinuum tożsamość poszerzona - tożsamość zraniona.

W rozdziale „Dziecko cudzoziemskie w nowym kraju. „Zderzenie kultur” omówione zostały główne problemy związane z funkcjonowaniem dziecka w sytuacji zmiany miejsca zamieszkania. Punktem wyjścia jest tu analiza procesów towarzyszących wchodzeniu dziecka w obszar nowej kultury. Ważną częścią rozdziału jest prezentacja wybranych aspektów różnic międzykulturowych konstruujących codzienność dziecka.

W kolejnym rozdziale, „Dziecko - uchodźca. Odebrane dzieciństwo (?)”, autorki koncentrują się na analizie wybranych problemów prawnych, społecznych i kulturowych, które często drastycznie rekonstruują dzieciństwo dzieci doświadczających uchodźstwa. W rozdziale zostały przywołane i omówione wybrane elementy wiedzy z zakresu zaspakajania potrzeb dziecka w kontekście etapów rozwoju psychospołecznego. Na tej podstawie autorki dokonały analizy poszczególnych etapów procesu stawania się uchodźcą oraz omówiły wybrane doświadczenia dzieci, które często w swej istocie są doświadczeniami traumatycznymi.

W rozdziale „Dziecko w społeczno-językowym kontekście emigracji zarobkowej rodziców” przedmiotem zainteresowania autorek stały się doświadczenia językowe, społeczne i kulturowe dwunastoletniego dziecka, którego matka podjęła decyzję o emigracji zarobkowej. Dziecko jest Ukraińcem, a państwem pobytu (w tej chwili już na stałe) jest Polska. Analiza i interpretacja doświadczeń migracyjnych dziecka pozwalają dostrzec, jak (re)konstruuje się jego świadomość społeczna i kulturowa i jakie podejmuje ono decyzje w zakresie wiedzy i umie- 
jętności kulturowych w obrębie kultur polskiej i ukraińskiej. W rozdziale zostały zaprezentowane wytworzone w świadomości dziecka przekonania językowe dla języków polskiego i ukraińskiego, a także angielskiego i rosyjskiego. Na ich podstawie autorki przybliżają wybory edukacyjne w zakresie języków, kultur polskiej i ukraińskiej, które w chwili badania deklaruje dziecko.

Część pierwszą zamyka rozdział „Sytuacja dziecka w rodzinie reemigrantów. Znów u siebie (?)”, w którym podejmowana jest próba rozpoznania sytuacji powrotu, która jest psychologicznie i społecznie trudna, tak dla dorosłego, jak i dziecka. Dziecko reemigrantów to dziecko doświadczające migracji powrotnej, a powodzenie jego powrotu i adaptacja społeczno-kulturowa po powrocie do kraju, jest tak samo trudna i skomplikowana jak rodziców. Rozdział rozpoczyna się omówieniem readaptacji rodziców dzieci. Uwaga czytelnika została zwrócona na problemy społeczno-tożsamościowe towarzszące powrotowi. Następnie, na tym tle, zostały przeanalizowane wybrane kwestie akulturacji i (re)konstruowania się tożsamości dziecka za granicą i po zakończeniu migracji.

Druga część monografii „Dziecko - edukacja: (wielo)kulturowe przetwarzanie dzieciństwa” poświęcona jest diagnozie dziecka jako uczestnika instytucjonalnych (zorganizowanych) sytuacji edukacyjnych. Te zaś, w rozpoznaniu autorek, stanowią społeczno-kulturowy kontekst nie tyle wytwarzania dzieciństwa, ale aktywnego przetwarzania dzieciństwa.

Część drugą rozpoczyna rozdział „Dziecko w świat „rzucone”. Ku tożsamości antropologiczno-kulturowej”, w którym autorki dokonują rozpoznania przestrzeni jako tego, co geograficzne i kulturowe, i co jednocześnie decydować może o kształtowaniu człowieka otwartego lub zamkniętego. Relacja otwarcie - zamknięcie jest antropologicznym odniesieniem, z którym człowiek mierzy się z konieczności, tylko dlatego albo aż dlatego, że został w ten świat rzucony. Wyprowadzona w tym rozdziale tożsamość antropologiczno-kulturowa jest warunkiem otwartości człowieka na wielość kultur, które mogą „dawać” człowiekowi rozumowy i (w pewnym sensie) afektywny asumpt do ciągłego poszerzania swej tożsamości. Tożsamość antropologiczno-kulturowa, w najszerszym sensie, jest propozycją tożsamościową, która wychodzi poza ciasne intelektualizmy czy kostniejące nacjonalizmy.

Drugi rozdział „Dziecko „etniczne” i szkoła. Etniczność jako źródło cierpień” okazał się w badaniach autorek istotny, ze względu na to, że ukazały w nim proces wytwarzania poczucia tożsamości na podstawie analizy i interpretacji doświadczeń biograficznych dziesięcioletniego „dziecka etnicznego”. Doświadczenia te są tym bardziej znaczące, że dziecko, którego doświadczenia stały się przedmiotem badania, jest wychowywane w rodzinie, w warunkach dwujęzyczności i dwukulturowości. Szkoła, w doświadczeniach dziecka „etnicznego”, stanowić może 
przestrzeń, w którym uzyska ono dostęp do wiedzy społecznej, która potwierdzi jego domowe/rodzinne doświadczenia dwukulturowości bądź im zaprzeczy. Różnica kulturowa, której dziecko doświadcza w sytuacjach szkolnych, warunkuje jego społeczne zachowania, nieustannie (re)konstruuje jego rozumienie siebie i otaczającego świata społeczno-kulturowego i tym samym nieustannie przetwarza jego dzieciństwo.

Kolejny rozdział „Dziecko w grupie zróżnicowanej kulturowo. Konteksty międzykulturowej edukacji formalnej” dotyczy wybranych zagadnień związanych z procesami edukacji i integracji dziecka w grupie zróżnicowanej kulturowo, które planowane i realizowany są w realiach edukacji formalnej (szkolnej). Analizę autorki rozpoczynają od omówienia istoty edukacji międzykulturowej i na tej podstawie przedstawiają argumenty na rzecz konieczności realizacji tego typu edukacji wśród dzieci. Rozdział prezentuje autorską koncepcję teorii praktyki, która koncentruje się na międzykulturowym waloryzowaniu procesu wychowawczego w ramach edukacji formalnej obejmującej grupy zróżnicowane kulturowo.

Ostatni rozdział książki nie tylko zamyka część drugą monografii, ale dopełnia także rozdział czwarty. Tekst „Dziecko - uczestnik międzykulturowej edukacji nieformalnej” ukazuje dziecko w sytuacji partycypacji w inicjatywach edukacyjnych o zróżnicowanej specyfice, przy czym chodzi o praktyki planowane i realizowane w ramach tzw. międzykulturowej edukacji nieformalnej. W rozdziale została zaprezentowana koncepcja międzykulturowej edukacji nieformalnej. Autorki wybrały te praktyki edukacji nieszkolnej (inicjowanej przez organizacje pozarządowe), w ramach których edukatorzy podejmują próbę dostrzeżenia dziecka jako podmiotu zaangażowanego w uczenie się międzykulturowości przez bycie w celowo organizowanych sytuacjach wielokulturowych.

Walorem monografii jest to, że badania, których wyniki zostały w niej zaprezentowane, wzbogacone zostały w warstwie interpretacyjnej o antropologiczny punkt widzenia. Umożliwia to humanistyczne, wrażliwe spojrzenie na dziecko i tym samym widzenie dziecka, które podobnie jak dorosły, jest podmiotem doświadczającym świat. W literaturze naukowej często pomijana lub pomniejszana jest rola dziecka, którego głos w naukowych narracjach jest słabo słyszalny lub nie jest w ogóle słyszalny.

Ilustracją rozważań teoretycznych podjętych w książce są praktyczne doświadczenia dzieci, ich rodziców, nauczycieli a także doświadczenia dorosłych, którzy do doświadczeń z dzieciństwa wracają. Autorki książki w doświadczeniach człowieka szukały nie tylko inspiracji do analiz naukowych, ale - przede wszystkim - w ludzkich biografiach poszukiwały odpowiedzi na nurtujące je pytania. Jak piszą, część empirycznych egzemplifikacji została przez nie pozyskana z wcześniej 
przeprowadzonych badań, inne zostały zrealizowane na potrzeby monografii. Wszystkie prezentowane badania miały charakter jakościowy, a wywiady były wywiadami narracyjnymi bądź biograficzno-narracyjnymi. Wcześniej zrealizowane wywiady były wywiadami kierowanymi i były inspirowane problematyką badań, w ramach których były prowadzone. W tej książce zostały one na nowo zinterpretowane zgodnie z podejściem konstruktywistycznym. Część wywiadów została zrealizowana na potrzeby książki i były to wywiady swobodne, inspirowane pytaniami problemowymi, które sugerował dany rozdział. Dostarczony przez te wywiady materiał empiryczny został również rozpoznany i zinterpretowany w ujęciu konstruktywistycznym.

Monografia ze względu na swą tematykę wpisuje się w pola teoretyczne i praktyczne szeroko pojętej edukacji międzykulturowej. Jej autorki podjęły trud rozpoznania i zrozumienia dziecięcych doświadczeń związanych z różnymi płaszczyznami jego funkcjonowania w warunkach różnicy. Książka może być przyczynkiem do dalszych dyskusji na ten temat. Jednocześnie może być wykorzystana przez praktyków podczas projektowania procesu edukacji dzieci w sytuacji zróżnicowania kulturowego oraz programów i projektów, których celem jest integracja międzykulturowa. 